Digitalizacja archiwalnych numerów czasopisma naukowego Analecta Cracoviensia 1-24 (1969-1992)

i ich publikacja w otwartym dostępie - zadanie finansowane w ramach umowy 672/P-DUN/2017 ze środków Ministra Nauki i Szkolnictwa Wyższego przeznaczonych na działalność upowszechniającą naukę

\title{
REALNE I ANALOGICZNE ISTNIENIE RZECZYWISTOS̃CI JAKO PODSTAWA KAŻDEJ FILOZOFICZNEJ AFIRMACJI BOGA
}

\begin{abstract}
„Filozofia św. Tomasza jest filozofią bytu ze względu na ,actus essendi", którego wartość transcendentalna jest najprostszą drogą poznania bytu samoistniejącego i Aktu Czystego - Boga".
\end{abstract}

JAN PAWEE II

Pytanie „czy istnieje Bóg”, wyłaniające się nie tylko z sytuacji kulturowo-socjologicznej, lecz także $\mathrm{z}$ osobistego przeżycia przygodności rzeczywistości, przede wszystkim $\mathrm{z}$ przeżycia przygodności człowieka, jest tylko pozornie pytaniem retorycznym. Faktycznie jest najważniejszym i najtrudniejszym problemem, który staje nie tylko przed filozofią czy teologią, lecz także przed każdym człowiekiem. Staje ono ze szczególną ostrością przed człowiekiem końca XX wieku. Wprawdzie współczesna kultura, zdominowana przez mentalność naukowo-techniczną i konsumpcyjny styl życia, zdaje się tę ostrość stępiać do tego stopnia, że nawet niektórzy teologowie zgodzili się go nie podejmować. „Teologia śmierci Boga" - chociaż zjawisko dość efemeryczne - jest tego dość wymownym przykładem. Nieprzypadkowo jednak obserwowane we współczesnej kulturze zjawisko „śmierci Boga” zbiega się ze „śmiercią człowieka". Mimo teoretycznej afirmacji godności osoby ludzkiej, praktycznie manipulacja człowiekiem wzrasta ${ }^{1}$. Ta zbieżność ,śmierci” potwierdza - poprzez doświadczenie historyczne - istotowe wprost związki zachodzące między problemem Boga i problemem człowieka.

Powstaje jednak pytanie, w jaki sposób wytłumaczyć to, że negacja osobowego Boga, ateizm, stał się faktem o niespotykanym dotychczas za-

1 Wiele mówi się obecnie o trudnej sytuacji człowieka po „śmierci Boga". Por. np. Le croyant devant la critique contemporaine, Paris 1975 (Wierzqcy wobec krytyki współczesnej, tłum. E. Burska, Warszawa 1978, zwłaszcza s. 41-52). E. Fromm, Anatomie der menschlichen Destruktivität, Stuttgart 1974, tenże To have or to be, New York 1976. 
sięgu, stał się - jak określa konstytucja o obecności Kościoła w świecie współczesnym - ,znakiem czasu" ${ }^{2}$.

Zapewne wiele i o różnym charakterze przyczyn na to się złożyło. Pragnę zwrócić uwagę na przyczyny filozoficzne, z których główną jest rezygnacja z realistycznego poznania metafizycznego, podejmującego najbardziej podstawowe doświadczenie ludzkie, jakie rodzi się $\mathrm{w}$ kontakcie $\mathrm{z}$ istniejącym światem, interpretującego je i wyjaśniającego przez wskazanie na ostateczne czynniki bytowe.

Drogę afirmacji (ew. negacji) Boga - jak zresztą drogę afirmacji wszelkiego przedmiotu - wyznaczają dwa czynniki:

$1^{\circ}$ natura poznającego podmiotu - jego sposób poznania, myślenia, mentalność ukształtowana przyjętą koncepcją nauki, racjonalności, filozofii,

$2^{\circ}$ natura poznawanego przedmiotu; w naszym przypadku chodzi o Boga rozumianego jako osobowy Absolut, transcendentny i zarazem immanentny w stosunku do poznającego podmiotu i do całego świata, byt nieuwarunkowany, który jest ostateczną racją wszystkiego, co istnieje.

Jest rzeczą zrozumiałą, że w pewnym typie poznania, przy wąskim rozumieniu racjonalności, a nawet $\mathrm{w}$ pewnych typach filozofii problem Boga się nie pojawia. Mentalność na nich ukształtowana zdaje się go nie dostrzegać. Nie wszystkie też afirmacje i negacje absolutu s̨̨ afirmacją lub negacją Boga.

Współczesny układ myśli jest dość konsekwentnym rezultatem drogi wytyczonej z jednej strony przez Descartesa, zradykalizowanej przez Kanta, a z drugiej - przez Comte'a i rozbudowanej przez scjentyzm. Filozofia naukowa i filozofia podmiotu wysunęly się na czoło myślowych nurtów naszych dni.

Jest już truizmem twierdzenie, że nauka nie posiada kompetencji rozstrzygania problemu istnienia Boga. Niemniej dominacja nauki, jej tendencje monistyczne i totalitarne, jej praktycyzm stały się jedną $\mathrm{z}$ ważnych przeszkód w afirmacji Boga. Nauka jest faktycznie niezmiernie ważnym czynnikiem sekularyzacji kultury i życia ludzkiego. Mentalność naukowo-techniczna prowadzi do ducha laickiego przez zawężenie pola widzenia, przez ograniczenie celów poznania, a w konsekwencji do zadań ludzkiego życia ${ }^{3}$.

Niemniej dla wielu naukowe poznanie w sensie pozytywistycznym stało się jedynie wartościowym poznawczym kontaktem ze światem i

${ }^{2}$ Konstytucja o obecności Kościoła w świecie współczesnym stwierdza, że „,ateizm należy zaliczyć do najpoważniejszych spraw doby obecnej”, p. 190 .

3 Istnieje na ten temat olbrzymia literatura, zob. choćby J. Ladrière, La science, le monde et la foi, Paris (Nauka, świat i wiara, tłum. A. Paygert, Warszawa 1978). 
jeśli dopuszcza się filozofię, to może ona stanowić wiedzę wtórną w stosunku do niego. Taki stan rzeczy znalazł bardzo istotny wyraz w problematyce afirmacji Boga. Usiłowano znaleźć - w ramach tego poznania - drogę Jego afirmacji, którą można określić jako drogę scjentystyczną.

Czyni się to na dwa sposoby:

1) wiążąc z refleksją nad powszechnie przyjętymi faktami naukowymi: biologicznymi (zwłaszcza faktem ewolucji - Teilhard de Chardin), socjologicznymi (ujęcia podurkheimowskie) czy psychologicznymi (przedstawiciele psychoanalizy),

2) wiążąc z analizą języka potocznego czy wprost religijnego (po L. Wittgensteinie) - np. I. T. Ramsey ${ }^{4}$.

Próby afirmacji Boga na drodze scjentystycznej - cenne i interesujące - stanowią jakiś uboczny produkt tego poznania, niezwiązany istotnie z pytaniem nauki współczesnej (jaka jest rzeczywistość, jak funkcjonuje, jak ją zmienić?). Opierają się na faktach i teoriach naukowych, które posiadają walor prawdopodobieństwowy, hipotetyczny. Wiążą się z obrazem świata, który w dużej mierze jest tworem człowieka, ma więc walor względny, który może być zburzony przez następnych badaczy.

Przeniesienie problemu w dziedzinę języka czy to filozoficznego (hermeneutyka), potocznego czy religijnego jeszcze bardziej wiąże afirmację Boga z ludzkimi wytworami, zwiększa ,zapośredniczenie" kultury, a właściwie całkowicie przenosi go na teren kultury, która jest pochodną od człowiekra, pogłębiając względność tej afirmacji (ew. negacji). Jej nieautonomiczny, już nie tylko w stosunku do nauki, lecz także wiary i teologii charakter, staje się ewidentny. Koło zamyka się ${ }^{5}$.

Drugi typ afirmacji (ew. negacji) Boga w myśli współczesnej, którą można by określić jako drogę, ,podmiotowo (świadomościową) - filozoficzną", wiąże się z tym nurtem filozofii, kitóry znalazł szczególny impuls w cogito Descartesa, został pogłębiony przez Kanta, który dokonał dalszej subiektywizacji poznania i pogłębił jego oderwanie od stanów realno-bytowych. Myśl a nie byt tkwi we wszelkich naszych aktach poznawczych. Refleksyjno-świadomościowy punkt wyjścia, nastawienie antropocentryczne i epistemiczne tego typu filozofii, która znalazła konkretny wyraz w dwu wielkich kierunkach myśli współczesnej fenomenologii i egzystencjalizmie, w kwestii afirmacji Boga dały rozwiązania różne — od afirmacji transcendentnego „Ty” jako korelatu ludzkiego

4 Por. S. Kamiński, Zagadnienie Absolutu $w$ filozofii scjentystycznej, w: O Bogu dziś, Warszawa 1974, s. 107-119 oraz W. D. Just, Religiöse Sprache und analytische Philosophie, Stuttgart 1973.

5 Jedynie możliwą wówczas ucieczką z tego jest przyjęcie „mitu” tak jak to czyni np. L. Kołakowski. Zob. jego Obecność mitu, Paryż 1973. 
„,ja” (Marcel), poprzez idealizm Husserla, przyjmującego ideę Absolutu jako rację o charakterze teleologicznym dla procesów konstytutywnych zachodzących w czystej świadomości, neutralność Heideggera, do ateizmu a nawet antyteizmu Sartre'a.

Przekonanie, że w filozofii świadomości nie można szukać ostatecznych podstaw dla stanów realnie istniejących, potwierdza występowanie $\mathrm{w}$ ramach tego samego nurtu filozoficznego rozwiązań diametralnie różnych. W ten sposób okazuje się skrajnie subiektywny charakter tej filozofii, która mając ogromne zasługi w dziedzinie penetracji ludzkiego wnętrza, okazuje się jednak nieadekwatna dla rozwiązania kwestii afirmacji Boga niezależnej od wiary religijnej. Wprawdzie analizując treść ludzkiej świadomości natrafia się na ideę Boga, jednak Jego afirmacja lub negacja ma charakter praktycznego postulatu, wyboru, decyzji myśliciela a nie jest „wymuszona” przez charakter badanej rzeczywistości.

Najbardziej konsekwentne stanowisko w kwestii afirmacji Boga zajął Heidegger, uważając, że aspekt jego filozofii wyklucza problem Boga $\mathrm{z}$ pola zainteresowania. Inna sprawa, że w tego rodzaju filozofii może nastąpić ontologizacja przyjętego aspektu - choć to nie leży w profilu takiej filozofii - i wówczas pojawia się problem jakiejś sfery boskiej, przeżycia boskości. Może powstać epistemologia tego przeżycia. Nie jest to jednak wówczas problem realnego istnienia osobowego Boga ${ }^{6}$. Symptomatyczne jest pojawienie się w filozofii współczesnej problemu sacrum, wartości religijnej, doświadczenia religijnego itp.

Obserwując filozofię po Descartesie nietrudno dostrzec stopniowe przesuwanie się punktu wyjścia filozofii od podmiotu ludzkiego poprzez analizę jego przeżyć do wytworów ludzkich. Obecnie zdajemy się być zamknięci w dziedzinie wytworów i filozofia staje się przede wszystkim „myśleniem o kulturze".

Czy istnieje powrót $\mathrm{w}$ dziedzinę realnego poznania? Czy możliwa jest metafizyka dziś?

Odpowiedź zależy od rozstrzygnięcia problemu z zakresu filozofii nauki - monizm czy pluralizm w koncepcji nauki, w koncepcji racjonalności.

W dziejach naszej kultury pojawiły się trzy wielkie koncepcje nauki: Arystotelesa (poznać - wskazać na ostateczne czynniki ontyczne), Kanta (poznać - wskazać konieczne aprioryczne warunki poznania) i Comte'a (poznać - ujęte w doświadczeniu mierzalne fakty zinterpretować - o ile można matematycznie).

Powstaje pytanie, na czym polega prawdziwy postęp $w$ nauce, na syntezie powyższych koncepcji nauki, wykluczaniu czy dopełnianiu?

${ }^{6}$ Por. W. Biemel, L'Interpretation heideggérienne du Sacré chez Hölderin, w: Prospettive sul sacro, Roma 1974, s. 184-198 oraz zawartość całego tomu. 
Synteza metodologicznie jest niemożliwa, nie ma bowiem jakiejś polimetody. Wykluczanie gubi ważne wymiary rzeczywistości, czego doświadczamy w kulturze współczesnej zdominowanej przez monizm naukowy. Jedynie racjonalne stanowisko, to ich dopełnienie przez uwzględnienie takiego typu filozofii, jako poznania naukowego i racjonalnego, który nie jest wtórny w stosunku do nauk szczegółowych, ani nie zamyka się $\mathrm{w}$ kręgu świadomości, która nie będąc pierwszą (pierwotną) daną, nie może stanowić podstawy dla pełnego poznania świata.

Niewątpliwie, filozofia jest związana $\mathrm{z}$ obrazem świata, $\mathrm{z}$ ogólną sytuacją kultury, z zaakceptowaną teorią nauki. Posiada jednak własne konstytuujące ją elementy, wewnętrzne prawa, wyznaczone obranym przedmiotem oraz podstawowym pytaniem. Tłumaczy to wielość filozofii, wielość uzasadnioną - jedna nie może zastąpić drugiej, a więc nie może jej wyeliminować.

A przecież filozofia w podstawowym, klasycznym sensie jest ukonstytuowana przez pytanie o czynniki ostatecznie wyjaśniające rzeczywistość (,dzięki czemu coś jest raczej niż nie jest”, „dzięki czému jest tym właśnie a nie tamtym”, ,dzięki czemu rzeczywistość jest rzeczywistością") i szuka przedmiotowego uzasadnienia dla istniejącej rzeczywistości.

Taka filozofia nie może się zdezaktualizować, bo rzeczywistość nieustannie narzuca człowiekowi pytania, stawia problemy, jest bowiem z samej natury „pytajna”. Choć wychodzi z analizy obiektywnie istniejącej rzeczywistości nie jest to filozofia pomijająca człowieka i jego problemy. Przeciwnie, wydaje się najbardziej antropologiczna, bo związana organicznie $\mathrm{z}$ najbardziej ludzkim, radykalnym doświadczeniem człowieka, jakie stanowi doświadczenie własnego bytu, doświadczenie swojej pozycji w bycie, ograniczenia, egzystencjalnej kruchości, słowem przygodności bytowej, wyrażającej się w normalnym „strachu” przed śmiercią, w braku jej akceptacji, w potrzebie zakotwiczenia $\mathrm{w}$ bardziej trwałym bycie, utrwalenia swego bytowania. Jest to doświadczenie tak fundamentalne, tak powszechne, że przekracza wszelkie społeczne czy naukowe uwarunkowania i formacje kulturowe. A człowiek nie jest „zamkniętą monadą” czy „wyspą samotną". Podstawowe doświadczenie egzystencjalne rodzi się $\mathrm{w}$ wyniku kontaktu $\mathrm{z}$ otaczającą człowieka rzeczywistością, z kontaktu z bytem. W analizie filozoficznej nie można tego podstawowego kontaktú z realnie istniejącym bytem zerwać, jeśli chodzi nam o wyjaśnienie realnie istniejącej rzeczywistości i jeśli chcemy zdobyć poznanie mające cechy adekwatności do tego, co dzieje się niezależnie od naszego myślenia (poznać prawdę).

Filozoficzna problematyka istnienia Boga jest zatem związana $\mathrm{z}$ rzeczywistością jako rzeczywistością. Człowiek stanowi jej najwyższą 
formację, ale jest w niej zanurzony i od niej nie można go oderwać. Tylko w kontekście realnie istniejącej rzeczywistości, narzucającej egzystencjalne pytania, można postawić pytanie o istnienie realnego Boga.

Podstawy rozwiązań tego rodzaju są zakodowane w reliktach myśli klasyków filozofii, zwłaszcza Tomasza z Akwinu. Trzeba wszakże usiłować zrozumieć, co w rzeczywistości jest rzeczywiste, co w bycie jest jego bytową podstawą. Ten niezastąpiony typ filozofii klasycznej przywołał Jan Paweł II, gdy mówił: „filozofia św. Tomasza jest filozofią bytu ze względu na actus essendi, którego wartość transcendentalna jest najprostszą drogą poznania bytu samoistniejącego i Aktu Czystego - Boga".

Problem afirmacji Boga $w$ filozofii bytu to nie tylko problem analizy sformułowanych w niej dowodów. To problem bardzo szczególnego charakteru poznania, które stanowi poznanie najbardziej podstawowe i najbardziej integralne przez swój realizm, analogiczność i transcendentalny charakter.

Pierwszym aktem człowieka w jego poznawczym kontakcie ze światem jest afirmacja bytu dokonująca się w sądzie egzystencjalnym „,oś jest", ,ja jestem” (istnieję), przy czym akcent pada na samą faktyczność istnienia czegoś poza mną i mnie samego, faktyczność, którą muszę uznać, przyjąć na mocy oczywistości przedmiotowej. Tego rodzaju afirmacja bytu jest podstawą wszelkiego poznania i działania, jest ostateczną podstawą afirmacji bytu koniecznego - Boga ${ }^{7}$. Jak się to dzieje?

W nagromadzonym przez sądy egzystencjalne materiale empirycznym intelekt $w$ sposób intuicyjny (chodzi o intuicję intelektualną) ujmuje z całą oczywistością przedmiotową, że cokolwiek istnieje, musi być zarazem czymś (treść) istniejącym (akt istnienia). „Coś jest” — „byt jest czymś istniejącym" stanowi podistawowy, fundamentalny sąd o wszystkim, co istnieje. Sąd ten, wyrażający najistotniejszą prawdę bytu ujmuje zawartość pojęcia bytu. Wyrażony w zdaniu nosi miano ,pierwszego prawa bytu”. Prawo „dojrzane” i „odczytane” w rzeczywistości realnej obowiązuje w całym realnym świecie tak daleko jak tylko sięga dziedzina bytowości.

Choć istotną zawartość pojęcia bytu stanowi zarówno treść jak i istnienie - podstawą jego transcendentalności jest nie tylko to, że wszystko, co istnieje posiada element treściowy i egzystencjalny, ale specjalny, do pewnego stopnia wspólny - przede wszystkim w swojej funkcji uaktualniającej - charakter istnienia we wszystkich bytach. $\mathrm{Na}$ istnienie jako fundament transcendentalności bytu, zwraca uwage św. Tomasz: ,ipsum esse quod est communissimum (De sub. sep. VI, 43), quia

7 Ten typ poznania, który buduje się na afirmacji istnienia i stanowi specyficzne poznanie metafizyczne omówił i zanalizował szczegółowo M. A. Krąpiec, Por. Metafizyka, Poznań 1964, Lublin 1978, Człowiek $i$ prawo naturalne, Lublin 1975. 
res ad invicem non distinguuntur secundum quod esse habent, quia in h=c omnia conveniunt" (C. G. I, 26).

Transcendentalne pojęcie bytu, wyrażone w pierwszym prawie bytu czyli w zasadzie tożsamości (jedności relatywnej) okazuje niewystarczalność ontyczną rzeczywistości, której dotyczy i „odsłania” istnienie takiego bytu, w którym nie ma wewnętrznego złożenia, a który wyrażałby się $w$ sądzie jedności absolutnej czyli utożsamia treści i istnienia. Zarówno więc pojęcie bytu, jak i pierwsze prawo bytu, są ,otwarte”, tzn. dopuszczają - więcej, domagają się - możliwość istnienia desygnatu, który nie jest znany w bezpośrednim poznaniu i który przekracza świat bytów złożonych.

W pierwszym prawie bytu są więc zawarte implicite wszystkie dalsze tezy metafizyki. Treść pojęcia bytu narasta w miarę dalszych analiz i poznawania dalszych właściwości transcendentalnych i wyrażania ich treści w następnych prawach bytu - niesprzeczności i racji dostatecznej. One stanowią przedmiot dalszych szczegółowych analiz i interpretacji uwyraźniających, w wyniku których dochodzi się do stwierdzenia, że wszystko co istnieje, jest bytowo od Niego pochodne.

Przejście od sądu o jedności relatywnej do sądu o jedności absolutnej nie dokonuje się bezpośrednio w wyniku jakiejś intuicji czy wizji. Suponuje szereg nowych analiz, interpretacji, które bezspornie dowodzą pośredniości przejścia. Niemniej problem istnienia Boga tu się pierwotnie pojawia ze względu na niesamozrozumiałość afirmowanej w sądzie egzystencjalnym rzeczywistości, której podstawą jest nietożsamość treści $i$ istnienia. Sprawą zasadniczą $\mathrm{w}$ procesie przechodzenia od stwierdzenia istnienia bytów niekoniecznych do stwierdzenia konieczności istnienia Bytu Absolutnego jest pogłębienie charakteru danych pierwotnie w sądzie egzystencjalnym - treści i istnienia. Dalsze etapy wyjaśniania metafizycznego można by ująć w następujące zauważalne fazy:

$1^{\circ}$ analiza relacji zachodzącej między treścią $\mathrm{i}$ istnieniem $\mathrm{w}$ bycie, która doprowadza do stwierdzenia względnie koniecznej jedności w konkretnym bycie oraz braku ich całkowitej tożsamości (realna różnica między istotą i istnieniem).

$2^{\circ}$ ustalenie charakteru zjednoczonych a równocześnie nietożsamych elementów z punktu widzenia czynników konstytuujących poszczególne byty. Okazuje się, iż istnienie (fakt egzystencji) nie konstytuuje natury konkretu, nie jest ujmowane $w$ jego definicji, nie wypływa też $z$ elementów konstytuujących istotę, czyli jest czymś w stosunku do niej ,zewnętrznym", mimo że konstytuuje realność natury.

$3^{\circ}$ Ustalenie funkcji istnienia w poszczególnych bytach. Chociaż konkretne byty są niepowtarzalnymi „parami” treści i istnienia, to istnienie we wszystkich spełnia tę samą funkcję, mianowicie aktualizuje 
wszystkie treści, czyni je właśnie czymś rzeczywistym. Treść jest możnością w stosunku do istnienia, będącego aktem.

$4^{\circ}$ Fakt transcendentalnej relacji między istotą $i$ istnieniem $\mathrm{w}$ bytach konkretnych, przy równoczesnej ich nietożsamości prowadzi do postawienia problemu ,zewnętrznej przyczyny tego istnienia, a fakt tożsamości funkcji istnienia we wszystkich bytach prowadzi do postawienia pytania o istnienie przyczyny transcendentnej. Skoro bowiem istnienie (czy jakaś inna doskonałość transcendentalna) znajduje się realnie we wszystkich bytach, nie wyczerpując się $\mathrm{w}$ żadnym $\mathrm{z}$ nich, bo zawsze jest ono różne od istoty tychże bytów, to nie może pochodzić od żadnego $\mathrm{z}$ bytów, w których istnienie jest czynnikiem konstytuującym naturę, ale jedynie od bytu, którego istotą jest istnienie.

Dokładną analizę i interpretację transcendentalności istnienia przeprowadza Tomasz w Sumie filozoficznej, II, 15:

a) Skoro coś przysługuje dwom albo wielu rzeczom, to wyrika $z$ tego, że $w$ żadnej z nich nie ralizuje się w pełni (jako takie), a poza tym, jeśli dwie rzeczy posiadają tę samą właściwość, to jedna może być przyczyną zaistnienia tej właściwości w drugiej, albo musi istnieć coś odrębnego poza danymi rzeczami, co jest przyczyną istnienia tej właściwości w pozostałych przedmiotach. Istnienie (esse) przysługuje wszystkiemu co jest, wobec czego musi istnieć przyczyna, która sama nie ma przyczyny istnienia, a od której ontycznie pochodzi wszystko, co istnieje.

b) Jeśli coś należy do jakiegoś bytu na mocy jego natury, to nie może być w tej dziedzinie ustopniowania. Coś, co istotowo z danym przedmiotem byłoby związane i uległo zmniejszeniu czy zwiększeniu, spowodowałoby zmianę natury tego przedmiotu. Jeśli natomiast czemuś przysługuje coś mniej niż innemu, nie przysługuje mu to na mocy samej jego natury lecz pochodzi od jakiejś innej przyczyny. Metafizyczna analiza rzeczywistości ukazuje realizowanie się istnienia $\mathrm{w}$ różnych przedmiotach, wobec czego istnieje byt utożsamiający bezwzględnie swoją istotę $\mathrm{z}$ istnieniem (Absolut), będący przyczyną wszystkiego, co istnieje.

c) Istnieje odpowiedniość pomiędzy porządkiem przyczyn i skutków, ponieważ skutki są proporcjonalne do przyczyn. Jeśli więc skutki właściwe sprowadzają się do właściwych przyczyn więc to, co wspólne jest w skutkach właściwych, sprowadza się do jakiejś wspólnej przyczyny. Wszystkim zaś wspólne jest istnienie (esse). Istnieje więc przyczyna, której istotą jest udzielenie istnienia.

d) Absolut jest bytem najbardziej aktualnym i jako taki jest sprawcą wszystkich aktualności i doskonałości wszystkich rzeczy.

Powyższy tok rozumowania streszcza św. Tomasz: „Ipsum enim esse est communissimus effectus, primus et intimior aliis effectibus, et ideo 
soli Deo competit secundum virtutem propriam talis effectus (De Pot. $5,7)^{8}$.

Tę drogę przejścia od afirmacji bytu realnego i analogicznego do konieczności przyjęcia Absolutu określa się w tradycji filozoficznej jako metodę analogii transcendentalnej ${ }^{9}$. Rozważając ją od strony bardziej formalnej, trzeba stwierdzić, że jej podstawą jest względne zjednoczenie, powtarzające się wewnątrz poszczególnych bytów. Jest to tzw. analogia wewnątrzbytowa wyrażająca analogiczność (złożoność, relacyjność) konkretnego bytu będącego jakąś istniejącą treścią. Następnie analogia międzybytowa, która wyraża relatywną tożsamość relacji i ich konieczne związki przyczynowe. W poszczególnych konkretach (analogatach) znajdują się elementy proporcjonalnie takie same. Proporcjonalność - nie typu matematycznego, lecz jako adekwatne przyporządkowanie - dotyczy jedynie takich elementów, które nie są ograniczone do jakiejś kategorii bytów, lecz odnoszą się do wszystkiego, co istnieje.

Jest to więc transcendentalna analogia proporcjonalności właściwej, gdyż opiera się na jedności proporcji wzajemnie powiązanych relacjami koniecznymi oraz na strukturze relacji transcendentalnych, obejmujących przyczyny zewnętrzne w całym zakresie ich działania.

$\mathrm{Na}$ tej więc drodze odczytania bytu w perspektywach ostatecznych uwarunkowań ontycznych powstaje konieczność przyjęcia istnienia ${ }^{\circ} \mathrm{Ab}-$ solutu jako przyczyny istnienia bytów niekoniecznych i jako pełni doskonałości, realizowanych w sposób częściowy, ograniczony, potencjalny przez poszczególne byty niekonieczne. Fakt istnienia różnych treści byłby niezrozumiały, jeśliby nie przyjęło się Pełni Istnienia wyjaśniającego realne, proporcjonalne stany zjednoczenia istoty i istnienia w bytach. Poszczególne zaś istniejące aktualnie treści są niezrozumiałe bez przyjęcia istnienia absolutnego, niezdwojonego.

W ten sposób, dzięki metodzie analogii transcendentalnej, będącej naczelnym wyrazem analogii proporcjonalności właściwej, opartej na relacjach transcendentalnych przede wszystkim relacji istoty i istnienia w bytach, dochodzi się do stwierdzenia:

$1^{\circ}$ analogicznej jedności konkretu - wszystko, co istnieje, jest wewnętrznie złożone, ale stanowi jeden byt dzięki jednemu aktowi istnienia.

$2^{\circ}$ analogicznej jedności całego kosmosu. Poszczególne byty, stanowiące swoiste złożenia, niepowtarzalne w swojej oryginalności, stanowią

8 De Pot. 5, 7.

9 Dokładną analizę i interpretację transcendentalności istnienia przeprowadza Tomasz w C. G. II, 15 passim. Myśl Tomasza jest nawiązaniem, choć w oparciu o własną koncepcję bytu, do tego, co napisał Arystoteles w Met. A. rozdz. VII o absolutnym pierwszeństwie aktu bytowego przed możnością. 
złożenia proporcjonalne w stosunku do innych, przy czym podstawą jedności jest jednakowa funkcja istnienia w każdym bycie.

$3^{\circ}$ Jedności Absolutnej, tożsamości wykluczającej wszelkie złożenie.

$4^{\circ}$ koniecznego powiązania przyczynowego poszczególnych jedności względnych z Jednością Absolutną. Wiszystko, co istnieje, okazuje się bytem istniejącym na zasadzie pochodności, złączenia, koniecznego związ$\mathrm{ku} \mathrm{z}$ Absolutem, a więc na zasadzie partycypacji. Każdy analogat (konkretny byt) w analogii transcendentalnej jest związany całą swą treścią z analogiczną doskonałością czyli analogonem - Istnieniem.

Aktualizowanie przez jeden akt istnienia konkretnej treści sprawia jedność bytu, która jest jednością analogiczną, gdyż inne byty, aktualizowane przez inne akty istnienia, stanowią również pewną, choć inną jedność. Każdy byt jest jednością i cały kosmos jest jednością analogiczną właśnie z racji jedności funkcji istnienia we wszystkich bytach oraz wzajemnych powiązań między bytami. Wymaga to przyjęcia Jedności Absolutnej jako przyczyny wyjaśniającej jedność analogiczną poszczególnych konkretów i jedność całego kosmosu.

Analogia transcendentalna, jako sposób poznania Absolutu w oparciu o sposób istnienia bytów niekoniecznych, stanowi teoriopoznáwczą podstawę dla teorii partycypacji, rozumianej jako realne, konieczne, przyczynowe, w zakresie przyczyn zewnętrznych (sprawczej, wzorczej i celowej) powiązanie wszystkiego, co istnieje z Absolutem, który jest ${ }^{10}$.

Przedstawione w zarysach drogi afirmacji Boga ukazują drogę bytu jako szczególną, niezastąpioną, podstawową i suponowaną przez wszystkie inne. Droga bytu sięga bowiem najgłębiej w rzeczywistość realnie istniejącą, ujmuje ją w jej koniecznych bytowych podstawach i tam „spotyka” Absolut. Jest to mówiąc najkrócej droga ,przyzwolenia bytu na Byt" 11.

10 Na funkcję analogii transcendentalnej w poznaniu Boga zwrócił uwagę ostatnio Jan Paweł II, który powiedział: „Stawiając jako przedmiot właściwy metafizyki rzeczywistość "sub ratione entis« św. Tomasz wskazał na transcendentalną analogię bytu jako na kryterium metodologiczne formułowania zdań dotyczących rzeczywistości łącznie z Absolutem. Trudno przecenić znaczenie metodologiczne tego odkrycia dla badań filozoficznych, jak zresztą dla poznania ludzkiego w ogóle" (17. XI. 1979). Koncepcja analogii transcendentalnej. zob. M. A. Krąpiec, Teoria analogii bytu, Lublin 1959.

11 Analogia transcendentalna, jako sposób poznania Absolutu w oparciu o sposób istnienia bytów niekoniecznych stanowi podstawę dla teorii partycypacji, rozumianej jako realne, konieczne, przyczynowe, w zakresie przyczyny zewnętrznych (sprawczej, wzorczej i celowej) powiązanie wszystkiego, co istnieje z Absolutem. Zob. Z. J. Zdybicka, Partycypacja bytu. Próba wyjaśnienia relacji między światem. $i$ Bogiem, Lublin 1972. Droga do afirmacji Boga przez afirmację bytu jest najbardziej naturalna i spontaniczna, dostępna każdemu myślącemu człowiekowi w ramach nawet poznania przednaukowego. Rozum ludzki $\mathrm{w}$ kontakcie $\mathrm{z}$ rzeczywistością niemal natychmiast dostrzega konieczność powiązania bytu zmiennego, niekoniecznego, będącego datum naszego doświadczenia $\mathrm{z}$ koniecznością afirmacji Absolutu. Biorąc to pod uwagę E. Gilson twierdzi, że przekonanie o istnieniu Boga 


\section{REAL AND ANALOGICAL EXISTENCE OF REALITY AS THE BASIS OF EVERY PHILOSOPHIAL AFFIRMATION OF GOD}

\section{S u m m a r y}

Tracing the development of contemporary philosophy we notice a gradual change in the object of philosophical cognition. Non-subjective reality has been replaced by a human subject and human experiences (existentialism, a philosophy of dialogue, a philosophy of encounter). Recently, human creation', escepically language and socio-cultural systems (analytical philosophy, structuralism, hermeneutics) have become the matter of philosophical reflection. Philosophy, then, has been separated from the really existing world. The relativisation of cognition and the impossibility of arriving at the truth are a simple consequence of this. This type of cognition also finds expression in the relativisation of the affirmation of the existence of God.

Here there arises an immediate need for philosophy in the classical sense which aims at cognizing and explaining actually existing reality by pointing to ultimate ontic reasons (,thanks to which something exists", ,thanks to which it is such as it is").

Pope John Paul II reminded us of value of such a philosophy, especially in solving the problem of the existence of God. "The philosophy of St. Thomas is a philosophy of being on account of the 'acfus essendi', whose transcendental value is the shortest way of arriving at a knowledge of Autonomous Being and Pure Act - God".

The author explains the nature of realism and of analogical and transcendental character of cognition in the philosophy of being. The affirmation of the existence of many concrete beings, expressed in existential judgments, guarantees realism. The cognition of an internal structure and the comprehension of existing items of these elements which are common to all beings (potency-act, essence-existence) assures transcendentalify. Analogy is a consequence of realism and transcendentality. Fundamental composition of being in each individual concrete being maintain the same proportions. The proportional complexity of all beings known to us from experience requires the acceptance of the existence of a non-complex Being, Pure Act, Absolute Existence, who is the ultimate ontic reason for the existence of proportionally complex, changeable, non-contingent beings.

jest czymś naturalnym i spontanicznym, natomiast trudnym do zrozumienia i wymagającym wyjaśnienia jest negacja Boga, ateizm. Por. L'atheisme difficile, Paris 1979, s. 12. 